\title{
Encontros e desencontros na identificação dos indicadores de Altas Habilidades/Superdotação
}

\author{
Agreements and disagreements in the identification of High Ability/Giffedness indicators
}

Susana Graciela Pérez Barrera Pérez ${ }^{[0]}$

\footnotetext{
${ }^{[a]}$ Doutora em Educação pela Pontifícia Universidade Católica do Rio Grande do Sul (PUCRS), sócia-fundadora e membro da Comissão Técnica do Conselho Brasileiro para Superdotação (ConBraSD), membro do Conselho Técnico da Associação Gaúcha de Apoio às Altas Habilidades (AGAAHSD), da Ficomundyt e do Grupo de Pesquisa CNPq da UNIP Inteligência e Criação: práticas educativas para Portadores de Altas Habilidades, Porto Alegre, RS - Brasil, e-mail: susanapb@terra.com.br
}

Recebido: 04/11/2011 Received: 11/04/2011

Aprovado: 25/11/2011 Approved: 11/25/2011

\begin{abstract}
Resumo
A inclusão mais clara dos alunos com Altas Habilidades/Superdotação (AH/SD) nas políticas públicas educacionais brasileiras tem levado a um crescimento na procura e uso de instrumentos para a identificação dos indicadores de AH/SD, tanto no ensino regular quanto no Atendimento Educacional Especializado em salas de recursos multifuncionais, conforme determinam os documentos mais recentes. Um dos instrumentos utilizados para a identificação desses indicadores em alunos do Ensino Fundamental é a Lista de Itens para Observação em Sala de Aula, formulado por Guenther $(2000,2006)$ para ser aplicado no contexto escolar. Entretanto, na prática, o uso desse instrumento tem sido associado a referenciais teóricos de inteligência não compatíveis com os pressupostos que embasam esse instrumento, o que traz, como resultado, a identificação, prioritariamente, de um único perfil de alunos, os do tipo acadêmico em áreas valorizadas pela escola, e de outros que, mesmo apresentando um bom desempenho escolar, não têm indicadores de AH/SD; do mesmo modo, outro resultado é a não identificação de alunos que, mesmo apresentando indicadores de $\mathrm{AH} / \mathrm{SD}$, não cumprem como os critérios privilegiados pelo mesmo. 0 objetivo deste artigo é analisar e discutir esses pressupostos, favorecendo sua melhor compreensão, apontando os aspectos que impedem a identificação de uma parcela de alunos que apresentam habilidade acima da média, comprometimento com a tarefa e criatividade - os três conjuntos de traços que definem as pessoas com AH/SD; o intuito é de contribuir para a melhor contextualização do uso desse instrumento, promovendo uma aplicação com consciência de suas limitações e/ou mesmo uma reformulação ou adaptação dele.
\end{abstract}

Palavras-chave: Altas Habilidades/Superdotação. Inteligência. Instrumentos de identificação.

\section{Abstract}

Clearer inclusion of highly able/gifted students in the Brazilian public educational policies has led to an increasing search and use of instruments to identify High Ability/Giftedness (HA/ GT) indicators, both in regular education and in the Specialized Educational Services offered in multifunctional resource rooms, as stated by the most recent documents. One of the instruments used to identify these indicators in elementary school students is the classroom observation checklist developed by Guenther $(2000,2006)$, to be applied within the school context. 


\begin{abstract}
However, in practice, the use of this instrument has been associated to intelligence theoretical references not compatible with the instrument grounds, thus resulting in the identification of only one profile of students, mainly, those academic students in school-valued fields; of other students that even having school achievement, have no HA/GT indicators, also failing to identify students that, even presenting HA/GT indicators, do not comply with the instrument prevailing criteria. This paper aims at analyzing and discussing these grounds, enhancing its understanding, pointing out those aspects impairing the identification of part of the students presenting above average ability, task commitment and creativity - the three clusters of traits defining HA/GT persons - intending to contribute to a better contextualization of the use of such instrument, promoting its application being aware of its restrictions and/or even its reformulation or adjustment.
\end{abstract}

Keywords: High Ability/Giftedness. Intelligence. Identification instruments.

\section{Introdução}

A identificação de alunos com Altas Habilidades/ Superdotação (AH/SD) nas escolas brasileiras é uma prática crescente e necessária, fundamentalmente a partir da aprovação da nova Política de Educação Especial na Perspectiva da Educação Inclusiva (Brasil, 2008a); do Decreto n. 6.571/08 (Brasil, 2008b), que determina a adjudicação de matrícula adicional para os alunos atendidos por essa modalidade, e do Parecer n. 13 e da Resolução n. 4 do Conselho Nacional de Educação, que determinam o atendimento educacional especializado (AEE) a essa parcela de alunos com necessidades educacionais especiais, definindo suas diretrizes operacionais nas Salas de Recursos Multifuncionais. À medida que o AEE começa a ser implantado e/ ou ampliado, a identificação, antes feita principalmente por profissionais da área da Saúde (psicólogos e neurologistas), transfere-se para o campo da Educação, tendo como protagonista o professor especializado e o professor de sala de aula regular, que deverá contribuir de forma fundamental com seu conhecimento sobre esses alunos.

Diversos instrumentos têm sido desenvolvidos, adaptados e utilizados para o processo de identificação, partindo das informações obtidas dos próprios alunos, dos colegas, dos familiares e dos professores. Um deles, a Lista de Itens para Observação em Sala de Aula (Guenther, 2000), é uma lista de indicadores que tem sido amplamente utilizada por profissionais da Educação para fazer a primeira triagem de alunos com AH/SD e, em alguns casos, mesmo para identificá-los, por sua facilidade de aplicação e interpretação e por se tratar de instrumento validado há vários anos.

0 instrumento foi inicialmente desenvolvido para atender a uma comunidade específica - escolas da cidade de Lavras (MG) - onde está sediado um Centro de Desenvolvimento de Talentos (CEDET), para o qual são encaminhadas, para atendimento durante um ano, as crianças indicadas por esse instrumento como potenciais "bem-dotadas (ou dotadas) e talentosas", conforme a terminologia utilizada por Guenther (2000).

Seja por diferenças culturais, especificidades da comunidade em que o CEDET está instalado, ou mesmo pelas concepções de inteligência e de superdotação que subsidiam o instrumento, a aplicação da Lista de Guenther (2000) em outras comunidades, na prática, tem apontado índices bem superiores aos aferidos por Guenther $(2000,2006)$, que variam de 10 a $25 \%$ dos alunos de uma turma, não conseguindo indicar alguns estudantes que apresentam indicadores de AH/SD, e indicando outros que não apresentam esse comportamento.

Por outro lado, o uso da Lista como instrumento de identificação, e não de indicação, também tem contribuído para atribuir índices de incidência das AH/SD irreais, que não acompanham os resultados de pesquisas científicas. Muitas vezes, esses índices também são produto da interpretação errônea de bibliografias estrangeiras. Se não existem estatísticas oficiais quanto à verdadeira incidência das AH/SD na população brasileira, as pesquisas feitas nesse sentido, incluindo-se aqui as estimativas da OMS, variam de 3,5 a $7,8 \%$ (Guenther, 2000, 2006; Associação Brasileira para 
Superdotados-Seção Rio Grande do Sul [ABSDRS], 2001; Pérez, 2004).

Essas constatações motivaram uma análise do instrumento, no sentido de favorecer sua utilização mais segura e eficiente como parte do processo de identificação, especialmente em outros contextos e realidades nos quais o atendimento educacional posterior não siga os mesmos moldes que em Lavras.

Dessa forma, é necessário compreender a sistemática e a forma de aplicação original da Lista de Guenther (2000), assim como o referencial teórico de inteligência e superdotação que a embasa, para entender melhor quais os possíveis alunos com AH/ SD detectados por ela e que outros instrumentos ou procedimentos devem ser utilizados para que a identificação seja confiável.

Como alguns indicadores da lista e os critérios de interpretação foram revisados em 2006, mas sem apresentar uma especificação formal da sua aplicação e interpretação e como ela é mais utilizada na sua versão original (2000), a descrição do instrumento está baseada nessa primeira versão. $\mathrm{Na}$ análise do referencial teórico e da classificação das áreas/domínios, incorporo à discussão as alterações e os novos indicadores acrescentados na revisão de 2006.

\section{Descrição do instrumento original e do seu uso}

A folha de observação original é uma lista de 26 indicadores "... aleatoriamente distribuídos, e derivados das áreas de dotação e talentos" (Guenther, 2000 , p. 175), na qual se solicita ao professor de sala de aula regular que nomeie os dois alunos que mais se destacam na sua turma escolar em cada um dos itens do Quadro 1.

\section{Quadro 1 - CEDET - Lista de itens para observação em sala de aula (2000)}

1. Indique em cada item os dois alunos de sua turma, menino ou menina, que, na sua opinião, apresentam as seguintes características:

1) Os melhores da turma nas áreas de linguagem, comunicação e expressão;

2) Os melhores nas áreas de matemática e ciências;

3) Os melhores nas áreas de arte e educação artística;

4) Os melhores em atividades extracurriculares;

5) Mais verbais, falantes e conversadores;

6) Mais curiosos, interessados, perguntadores;

7) Mais participantes e presentes em tudo, dentro e fora da sala de aula;

8) Mais críticos com os outros e consigo próprios;

9) De melhor memória, aprendem e fixam com facilidade;

10) Mais persistentes, compromissados, chegam ao fim do que fazem;

11) Mais independentes, que iniciam o próprio trabalho e fazem sozinhos;

12) Mais entediados, desinteressados, mas não necessariamente atrasados;

13) Mais originais e criativos;

14) Mais sensíveis aos outros e bondosos para com os colegas;

15) Preocupados com o bem-estar dos outros;

16) Mais seguros e confiantes em si mesmos;

17) Mais ativos, perspicazes, observadores;

18) Mais capazes de pensar e tirar conclusões;

19) Mais simpáticos e queridos pelos colegas;

21) Mais levados, engraçados, "arteiros";

22) Que você considera mais inteligentes;

23) Com melhor desempenho em esportes e exercícios físicos;

24) Que sobressaem em habilidades manuais e motoras;

25) Que produzem respostas inesperadas e pertinentes;

26) Capazes de liderar e passar energia própria para animar o grupo;

2. Existe em sua turma alguma criança com outros talentos especiais? Quem? Como manifestam seu talento estes dois últimos alunos? (Pode anexar qualquer material que julgar pertinente).

3. Comentários e observações que deseje fazer. (Pode anexar folhas se desejar).

Fonte: GUENTHER, 2000, p. 175-177. 
Os critérios de avaliação desses indicadores são os apresentados no Quadro 2.

Antes de aplicar o instrumento, é feita uma preparação com os professores para uniformizar os conceitos e termos empregados na lista de itens para observação em sala de aula de Guenther (2000).

0 instrumento é preenchido pelo professor, num período aproximado de duas semanas, no último mês do ano letivo, nas turmas regulares (sem homogeneização por critérios de desempenho) do último ano da Educação Infantil até a $4 \underline{a}$ série (5a ano) do Ensino Fundamental, visto que, a partir da $5^{\text {a }}$ série ( $6^{\circ}$ ano), o conteúdo curricular é distribuído por disciplinas, e isso dificulta o conhecimento do aluno pelo professor (Guenther, 2000). Da 5a à 8a série (6ㅇa 9o ano), Guenther (2006) recomenda utilizar o mesmo instrumento com os professores das diferentes disciplinas, no Conselho de Classe, como forma de ter um coletivo de observadores que possam avaliar o desempenho do aluno em relação aos conteúdos que cada um deles leciona.

Posteriormente, os dados são processados segundo os critérios estabelecidos para sua interpretação, e a lista de alunos indicados é submetida à apreciação da equipe técnica da escola, supervisores, orientadores e diretores, discutindo-se outros dados disponíveis. Os alunos indicados passam a ser atendidos e observados no CEDET durante um ano, quando participam de atividades de enriquecimento, acompanhados por um facilitador (Guenther, 2000).

\section{Quadro 2 - Critérios de avaliaccão}

Capacidade e inteligências geral: A criança deve ser indicada em pelo menos 6 dos itens: 4, 6, 9, 10,11, 12, 17, 18, 21, 22, 25 ou em pelo menos 4 dos itens: 9, 11, 13, 17, 18, 22, 25 . Talento verbal: A criança deve ser indicada em pelo menos 3 dos itens: 1, 5, 7, 18, 22.

Capacidade de pensamento abstrato (talento científico-matemático): A criança deve apresentar três ou mais dos itens: $2,9,11,18,22$.

Criatividade acentuada e/ou talento artístico: Presença em pelo menos 4 dos itens seguintes, em qualquer combinação, ou três, incluindo os de n. 3 e 13: 3, 8, 10, 13, 17, 25. Talento psicossocial: Presença de pelo menos 4 dos itens: $4,7,14,15,16,19,26$. A presença dos itens 16 e 26 indicam liderança.

Talento psicomotor: Presença dos itens 4, 23 e 24

Fonte: GUENTHER, 2000, p. 181-184.
Ao final desse ano, são colhidas informações do professor atual da criança, o que permite obter dados de três fontes de informações sobre o mesmo aluno: o professor do ano anterior, o facilitador do CEDET e o professor atual. 0 aluno que tiver indicação de, pelo menos, duas das três fontes continua no atendimento do CEDET.

A expectativa de indicação desse instrumento é de 4 a 5\%; um estudo realizado para aferir o grau de validade do processo de identificação com o uso da Lista encontrou uma média de " $4,2 \%$ da população estudada como portadores de dotação e talento" (Guenther, 2000, p. 190), sendo que, segundo a autora, a Lei das Probabilidades prevê 5\%.

\section{0 referencial teórico da lista de itens para observação em sala de aula}

Antes de analisar o instrumento em si, é importante resgatar o referencial teórico (conceito de inteligência e de dotação ou talento) que o embasa, para se ter clareza do tipo de aluno que está sendo indicado com ele e dos critérios adotados para isso.

À diferença do bastante utilizado conceito multidimensional de Gardner (1983, 2000), que propõe oito inteligências diferentes (linguística, lógico-matemática, naturalista, espacial, musical, corporal-cinestésica, intrapessoal e interpessoal), Guenther (2000, p. 66) adota um conceito de inteligência multicomponencial, que integra "várias capacidades cognitivas, socioemocionais, perceptuais, físicas, fisiológicas e até intuitivas, funcionando em uma configuração maior em harmonia com o quadro de referência e posicionamento geral da pessoa". Entende-se, aqui, uma inteligência composta por diferentes capacidades, sendo que "capacidade é essa característica que torna possível o desempenho de alta qualidade, nos diversos setores e avenidas da atividade humana, propiciando alcançar elevados graus de sucesso" (Guenther, 2000, p. 27, grifos nossos).

Para Guenther (2000, p. 28, grifo nosso), "o talento implica na capacidade de desempenhar em elevado grau de qualidade, não apenas como indivíduo, mas também em comparação com o grupo maior detentor de características semelhantes". Ela também refere que a boa dotação caracteriza-se por um "... nível de qualidade do pensamento e/ou aceleração e avanço das funções cerebrais" expressado por "... elevados níveis de capacidades envolvidas 
na cognição, criatividade, insight, resolução de problemas ou colocação de questões relevantes" (Guenther, 2000, p. 66).

Nesse sentido, a autora concorda com a definição de Gagné da primeira versão do seu Modelo Diferenciado de Dotação e Talento (DMGT) (1991, p. 66), que entendia a "dotação" como a "... competência que é distintivamente superior à média em um ou mais domínios da aptidão humana" e talento como o "... desempenho [grifo nosso] que é distintivamente superior à média em um ou mais campos de atividade humana". Naquela definição do autor, a superdotação envolvia aptidões naturais, enquanto o talento equivalia a habilidades desenvolvidas.

Feldhusen (1995) também tenta diferenciar os termos superdotação e talento, entendendo a primeira como uma capacidade geral e unitária subjacente, e o talento como uma aptidão desenvolvida em certas áreas de atividade humana (um desempenho) "... em função da habilidade geral, g, ou inteligência e de suas experiências educacionais em casa, na escola e na comunidade. Essa capacidade geral equivale ao coeficiente intelectual" (Feldhusen, 2003, p. 263).

Grosso modo, a dotação para Gagné (1991), Feldhusen $(1995,2003)$ ou Guenther $(2000,2006)$ aparece como um supraestrato - uma capacidade, aptidão ou competência acima da média, geralmente de caráter genético - que encerra algumas características comuns, enquanto o talento implica, necessariamente, um desempenho.

Em uma publicação mais recente que atualiza o seu DMGT, Gagné (2009) apresenta algumas alterações nessas definições, estendendo o "desempenho" ao conceito de dotação que, para ele, "designa a posse e uso de capacidades naturais notáveis chamadas aptidões, em pelo menos um domínio de capacidade, a um grau que coloca o indivíduo pelo menos entre os $10 \%$ superiores no grupo de pares etários" (Gagné, 2009, p. 1, grifos nossos). 0 talento é entendido como

o domínio notável de habilidades sistematicamente desenvolvidas, chamadas competências (conhecimento e habilidades), em pelo menos um campo de atividade humana, a um grau que coloca o indivíduo entre pelo menos os $10 \%$ superiores no grupo de pares etários que são ou já foram ativos naquele campo (Gagné, 2009, p. 1, grifo do autor).
Assim, deve-se observar que a capacidade ou inteligência geral, proposta na lista, como conjunto de indicadores, corresponde ao conceito de superdotação ou dotação apoiado no construto de inteligência $g$ ou inteligência geral, enquanto as habilidades específicas desenvolvidas (o desempenho) constituem os chamados talentos (verbal, científico, artístico, psicossocial e psicomotor) (Guenther, 2000), posteriormente revisados (Guenther, 2006) e denominados domínios (da inteligência, da criatividade, socioafetivo e sensório-motor), que analisarei na sequência.

\section{As áreas ou domínios de talento da lista de itens para observação em sala de aula}

Bastante próximo ao referencial teórico do DMGT 1 de Gagné (1991), que definia quatro domínios de aptidões (ou superdotação) - intelectual, criativo, socioafetivo e sensório-motor - e cinco campos de talento - acadêmico, técnico, artístico, interpessoal e atlético; e de Feldhusen (1995), que propõe quatro áreas de talento - acadêmico-intelectual, artístico, técnico-vocacional e sociointerpessoal -, a lista aponta indicadores de capacidade e inteligência geral e de cinco áreas de talento: talento verbal e capacidade de pensamento abstrato/talento científico-matemático, que originariam o chamado talento acadêmico; criatividade acentuada e/ou talento artístico; talento psicossocial e talento psicomotor (Guenther, 2000). Na revisão de 2006, Guenther se aproxima ainda mais dos referenciais citados, distribuindo os indicadores do talento verbal, do pensamento abstrato/talento científico-matemático e da capacidade e inteligência geral (2000) nas duas avenidas de expressões que caracterizariam o domínio da inteligência (2006), clareando o conceito exclusivamente cognitivo desse domínio, que se manifesta, fundamentalmente, via inteligência linguística e/ou lógico-matemática.

Em sua revisão do DMGT, Gagné (2009, p. 2) desmembra os quatro domínios de aptidão originais, distinguindo "quatro mentais: intelectual (GI), criativo (GC), social (GS) e perceptual (GP) e duas capacidades físicas: muscular (GM), capacidades devotadas aos movimentos físicos amplos, e capacidades associadas com o controle motor fino e reflexos (GR)", normalmente utilizadas em atividades físicas complexas, como esportes e ginástica. 
Quanto ao talento, os cinco campos originais agora são nove: o campo acadêmico; seis campos baseados numa classificação do mundo laboral (técnico, ciência e tecnologia, artes, assistência social, administração/vendas e operações de negócios) e vinculados a tipos de personalidade (Realista, Investigativo, Artístico, Empreendedor, e Convencional); o campo de jogos e o de esportes (Gagné, 2009).

De fato, nas minhas experiências de aplicação desse instrumento, os alunos identificados como aqueles que apresentavam capacidade e inteligência geral, normalmente, também eram indicados em um ou nos dois talentos cognitivos (talento verbal e pensamento abstrato/pensamento científico-matemático). 0 Quadro 3 mostra os indicadores considerados na lista de 2000 e as alterações e/ou indicadores acrescentados em 2006 (cinza).

\section{Capacidade e inteligência geral/domínio da inteligência e capacidade intelectual}

A capacidade e a inteligência geral constituem, segundo Guenther (2000), um conjunto de "... sinais captáveis nos detentores de talento, acima e além de atributos específicos observáveis" (Guenther, 2000, p. 47) que, na teoria de Spearman, correspondem ao chamado fator $\mathrm{G}$. $\mathrm{O}$ aluno com essa capacidade deve combinar pelo menos seis indicadores do grupo de questões $4,6,9,10,11,12,17,18,21,22$ e 25 ou quatro indicações no grupo de questões $9,11,13$, $17,18,22$ e 25.

Dessa forma, percebe-se que memória e facilidade de aprendizagem (9), independência e autonomia (11), perspicácia e capacidade de observação (17), capacidade de pensar e tirar conclusões (18), inteligência (22) e pensamento divergente (25) são os indicadores considerados mais importantes da capacidade e inteligência geral, visto que são comuns aos dois blocos de indicadores que permitem identificar os alunos que a possuem.

De fato, Guenther (2000) reforça que o reconhecimento das crianças que apresentam essa inteligência e capacidade geral pode basear-se na aferição da vivacidade mental, revelada pela expressão da curiosidade e do questionamento (6), da apreciação dos desafios; do senso de humor (19); da memória (9); do domínio de um número considerável de conhecimento e informações, da facilidade de aprendizagem e compreensão $(9,17,18$ e 22$)$; e da automotivação e confiança, constatadas em crianças com opnião própria, independência (11), persistência (10), no compromisso com a tarefa e motivação intrínseca (10), no gosto por correr riscos e na iniciativa própria (11), sendo que essas crianças podem apresentar-se participativas (7), confiantes e seguras (16) ou autocontidas (20).

Condizente com os conceitos de Gagné (1991) e Feldhusen (1995, 2003), os indicadores da capacidade e inteligência geral são fundamentalmente de ordem cognitiva, com exceção dos itens 4 (melhores em atividades extracurriculares), que pode envolver alguma atividade não cognitiva, e 21 (mais levados, engraçados, "arteiros"), referente ao senso de humor, muito comum nas Pessoas com Altas Habilidades/Superdotação (PAH/SD). Esses dois itens são alternativos (aparecem somente em um dos conjuntos de indicadores), assim como os itens 6 (mais curiosos, interessados, perguntadores) e 13 (mais originais e criativos) - que, embora necessários para aferir a criatividade, também são de ordem cognitiva.

\section{Talento verbal}

O conjunto de indicadores identificador do talento verbal, na lista, inclui a indicação do aluno em pelo menos três dos seguintes itens: superioridade na área da linguagem, comunicação e expressão (1), fluência verbal (5), participação e presença em tudo dentro e fora da sala de aula (7), capacidade de pensar e tirar conclusões (18) e inteligência (22).

Na questão 1 (melhores da turma nas áreas de linguagem, comunicação e expressão), poderiam ser indicados aqueles alunos que apresentam melhor desempenho na área linguística (língua portuguesa e línguas estrangeiras), assim como também aqueles cujo destaque ocorre na área da comunicação e expressão (demonstrado, por exemplo, na representação teatral, na apresentação de trabalhos de quaisquer disciplinas e/ou quando o aluno apresenta liderança). Parece que essa questão atrela ambas as áreas (linguística e comunicação e expressão) a um único indicador. Um aluno que apresenta liderança e, portanto, tem facilidade para a comunicação e expressão, não necessariamente demonstrará bom desempenho na área linguística; pelo menos, não na forma tradicional de avaliação 
Quadro 3 - Indicadores da lista de 2000 e alteraç̃oes e/ou indicadores acrescentados em 2006

(Continua)

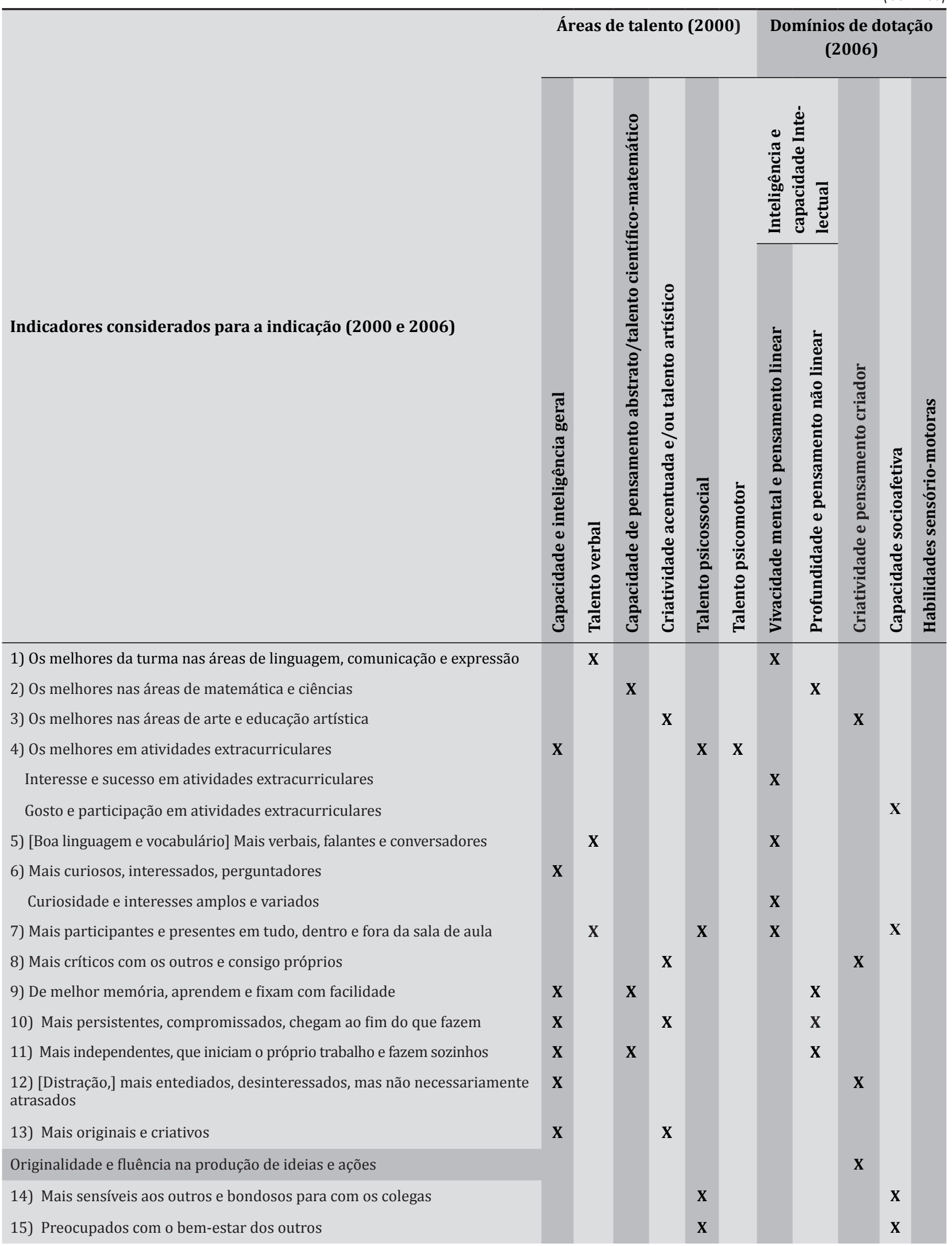


Quadro 3 - Indicadores da lista de 2000 e alterações e/ou indicadores acrescentados em 2006

(Conclusão)

\begin{tabular}{|c|c|c|c|c|c|c|c|c|c|c|c|}
\hline \multirow[b]{2}{*}{ Indicadores considerados para a indicação (2000 e 2006) } & \multicolumn{6}{|c|}{ Áreas de talento (2000) } & \multicolumn{5}{|c|}{$\begin{array}{c}\text { Domínios de dotação } \\
\text { (2006) }\end{array}$} \\
\hline & 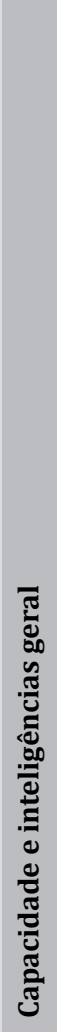 & 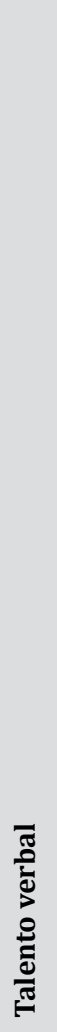 & 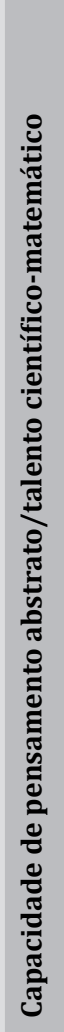 & 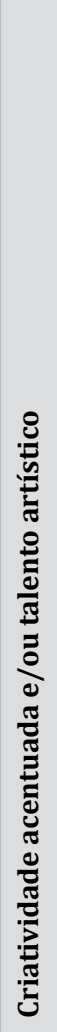 & 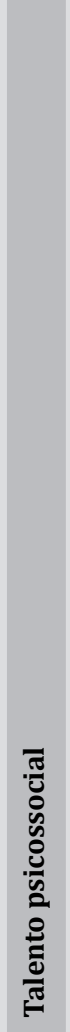 & 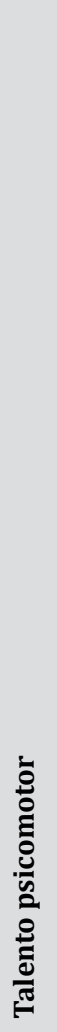 & 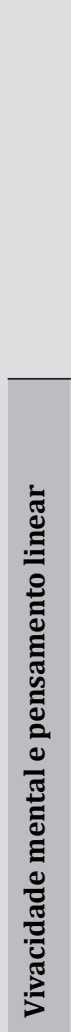 & 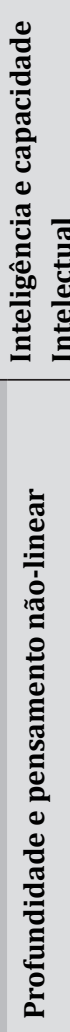 & 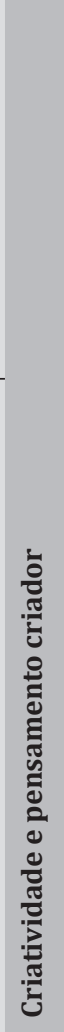 & 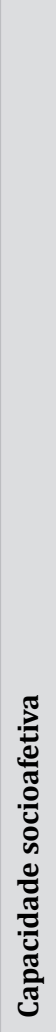 & 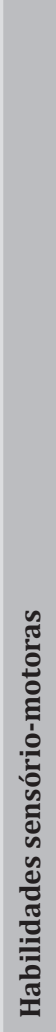 \\
\hline 16) Mais seguros e autoconfiantes & & & & & $\mathbf{x}$ & & & $\mathbf{x}$ & & & \\
\hline 17) [Vivacidade, sintonia,] mais ativos, perspicazes, observadores & $\mathbf{x}$ & & & $\mathbf{x}$ & & & $\mathbf{x}$ & & & & \\
\hline 18) [ Pensamento analítico,] mais capazes de pensar e tirar conclusões & $\mathbf{x}$ & $\mathbf{x}$ & $\mathbf{x}$ & & & & & $\mathbf{x}$ & & & \\
\hline 19) Mais simpáticos e queridos pelos colegas & & & & & $\mathbf{x}$ & & & & & & \\
\hline Simpatia, amizade, boas relações com colegas e professores & & & & & & & & & & $\mathbf{x}$ & \\
\hline 20) Mais solitários e ignorados & & & & & & & & & & & \\
\hline 21) [Senso de humor,] mais levados, engraçados, "arteiros" & $\mathbf{x}$ & & & & & & $\mathbf{x}$ & & & & \\
\hline 22) Que você considera mais inteligentes & $\mathbf{x}$ & $\mathbf{x}$ & $\mathbf{x}$ & & & & & & & & \\
\hline 23) Com melhor desempenho em esportes e exercícios físicos & & & & & & $\mathbf{x}$ & & & & & $\mathbf{x}$ \\
\hline 24) Que sobressaem em habilidades manuais e motoras & & & & & & $\mathbf{X}$ & & & & & $\mathbf{x}$ \\
\hline 25) Que produzem respostas inesperadas e pertinentes & $\mathbf{x}$ & & & $\mathbf{x}$ & & & & & $\mathbf{x}$ & & \\
\hline $\begin{array}{l}\text { 26) [Liderança, persuasão,] capazes de liderar e passar energia própria para } \\
\text { animar o grupo }\end{array}$ & & & & & $\mathbf{x}$ & & & & & $\mathbf{x}$ & \\
\hline $\begin{array}{l}\text { Existe em sua turma alguma criança com outros talentos especiais? } \\
\text { Quem? }\end{array}$ & & & & & & & & & & & \\
\hline Amplo acervo de conhecimentos e informações sobre muitos assuntos & & & & & & & & $\mathbf{x}$ & & & \\
\hline Desempenho superior em dança e outras formas de expressão rítmica & & & & & & & & & & & $\mathbf{X}$ \\
\hline $\begin{array}{l}\text { Extraordinário funcionamento dos sentidos: acuidade visual, sensibilida- } \\
\text { de auditiva, tátil, de olfato e gustativa }\end{array}$ & & & & & & & & & & & $\mathbf{x}$ \\
\hline
\end{tabular}

Fonte: Elaborado a partir de GUENTHER, 2000, p. 175-177 e GUENTHER, 2006, p. 87-88.

Nota: Indicadores acrescentados ou modificados na lista de 2006. 
da linguagem, que geralmente está muito baseada na correção gramatical e sintática e não na produção linguística em si.

A questão 5 (mais verbais, falantes e conversadores) poderia permitir a identificação de indicadores de AH/SD em duas inteligências diferentes (linguística e interpessoal), visto que um aluno pode ser o melhor na expressão verbal - denotando destaque na área linguística -, mas não necessariamente ser conversador, o que revela destaque na área interpessoal, ou vice-versa.

0 indicador 7 (mais participantes e presentes em tudo, dentro e fora da sala de aula) não é um indicador específico do talento verbal, mas da inteligência interpessoal e, inclusive, da liderança, embora envolva a comunicação feita, geralmente, por meio da inteligência linguística.

\section{Pensamento abstrato/talento científico-matemático}

0 pensamento abstrato/talento científico-matemático requer a indicação do aluno em pelo menos três dos seguintes indicadores: superioridade nas áreas de matemática e ciências (2); memória, facilidade de aprendizagem e fixação (9); independência e autonomia (11); capacidade de pensar e tirar conclusões (18) e inteligência (22).

Se observarmos os indicadores apontados para identificar capacidade e inteligência geral, talento verbal e pensamento crítico/talento científico-matemático, vemos que os itens 18 e 22 (capacidade de pensar e tirar conclusões e inteligência) estão presentes no rol de itens da capacidade e inteligência geral e no dos dois tipos de talento, e os itens $9 \mathrm{e}$ 11 (memória, facilidade de aprendizagem e fixação e independência e autonomia) são comuns à lista de indicadores de capacidade e inteligência geral e de pensamento abstrato/talento científico-matemático. Isso reforça o conceito de inteligência cognitiva, manifestada essencialmente via inteligência linguística e lógico-matemática.

A questão 2 (melhores em matemática e ciências) vincula duas disciplinas (matemática e ciências) que requerem o uso da inteligência lógico-matemática e/ou da inteligência naturalista.

Nas Ciências Naturais, os Parâmetros Curriculares Nacionais de $1^{\underline{a}}$ a $4^{\underline{a}}$ séries $\left(2^{\circ}\right.$ a $5^{\circ}$ ano) (Brasil, 1997) destacam três grandes eixos temáticos: ambiente, ser humano e saúde e recursos tecnológicos. Os conteúdos que podem ser abordados nesses eixos envolvem diferentes disciplinas das Ciências Naturais, como podem ser a biologia, a zoologia, a botânica, a astronomia, a física e a química, ora mais vinculadas à inteligência lógico-matemática (astronomia, física, química inorgânica), ora à inteligência naturalista (biologia, zoologia, botânica, química orgânica).

Dessa maneira, mesmo que o talento científico-matemático envolva ambas as inteligências, fundi-las sob um mesmo indicador abre a possibilidade de deixar de indicar uma criança que somente tenha superioridade em matemática e não em ciências ou vice-versa.

Assim como no talento anterior, a questão 22 embute no critério de indicação a associação entre o conceito de aluno nota 10 e um determinado conceito de inteligência, vinculado à superioridade na inteligência linguística e lógico-matemática e a características desejáveis do que se entende por pessoa inteligente, tais como persistência e compromisso com a tarefa, facilidade de aprendizagem, memória, observação, perspicácia e pensamento analítico.

\section{Domínio da inteligência e capacidade intelectual: capacidade e inteligência geral, talento verbal e pensamento abstrato}

Guenther (2006, p. 36) reorganiza a definição dos talentos (agora chamados de domínios), definindo duas avenidas de expressão para o domínio da inteligência e capacidade intelectual que ampliam um pouco as duas apresentadas em 2000 (vivacidade mental e a automotivação e confiança), mas que mantêm a caracterização básica de incluir os aspectos cognitivos como eixo central:

a) vivacidade mental e pensamento linear: bom domínio da comunicação; precisão e concisão na expressão verbal; avanço acadêmico nas áreas da linguagem falada e escrita; gosto e eficiência ao lidar com palavras; atenção e curiosidade; questionamento; gosto pelo desafio; senso de humor; memória destacada; considerável número de conhecimentos e informações; facilidade de aprendizagem por vários meios;

b) profundidade, pensamento não linear e abstrato: preferência por trabalhar sozinho; ritmo e estilo de trabalho pessoal; automo- 
tivação; confiança; cabeça própria; independência; persistência e compromisso com a tarefa; motivação mais interna do que externa; aceitação de riscos; iniciativa; capacidade de concentração; autoconfiança e segurança; responsabilidade; elevada capacidade de analisar, associar e configurar símbolos e conceitos; boa organização interna; raciocínio e lógica; capacidade de estabelecer relações e identificação de causas nos fenômenos observados; formação de conceitos a partir dos fatos.

Em 2006, o domínio da inteligência incorpora algumas características importantes, próprias das $\mathrm{PAH} / \mathrm{SD}$ (não especificadas na versão de 2000), que talvez possam ser relacionadas à questão 22 do questionário de 2000 (que você considera mais inteligentes), agora eliminada. De fato, os atributos "considerável fundo de conhecimentos e informações sobre muitos assuntos, ritmo e estilo pessoal; capacidade de concentração" e "elevada capacidade de analisar, associar e configurar símbolos e conceitos; boa organização interna; raciocínio e lógica; capacidade no estabelecimento de relações e identificação de causas nos fenômenos observados, formando conceitos a partir de fatos" (Guenther, 2006, p. 37) não estão diretamente relacionados a outros indicadores da lista de 2000.

Alguns indicadores da lista foram incorporados ao domínio da inteligência. Os itens 1 (melhores da turma nas áreas de linguagem, comunicação e expressão), 5 (mais verbais, falantes e conversadores) e 7 (mais participantes e presentes em tudo, dentro e fora da sala de aula), antes reservados ao talento verbal, exclusivamente; o item 2 (melhores nas áreas de matemática e ciências), reservado à capacidade de pensamento abstrato/talento científico-matemático; o item 16 (segurança e autoconfiança), relacionado ao talento psicossocial; e o "amplo acervo de conhecimentos e informações sobre muitos assuntos" (sem questão relacionada) agora fazem parte dos indicadores do domínio da inteligência. Dos indicadores de capacidade e inteligência geral (2000) foram retirados o 12 (mais entediados, desinteressados, mas não necessariamente atrasados); o 13 (originalidade e criatividade) e o 25 (que produzem respostas inesperadas e pertinentes), que agora fazem parte do domínio da criatividade e pensamento criador; além do item que pedia a indicação dos dois alunos que você considera mais inteligentes (22) que não mais aparece em domínio algum. A questão 4 (melhores em atividades extracurriculares) acrescenta a necessidade de sucesso nessas atividades.

Em 2000, Guenther (2000, p. 49) concordava com os teóricos quanto à criatividade e à capacidade intelectual serem interdependentes, e entendia, corretamente, que a criatividade pode se manifestar tanto na área científica quanto na artística, apontando como seus traços a "preferência pelo pensamento holístico, intuição e pensamento intuitivo, produção de objetos ou ideias", a originalidade, a fluência e o elevado senso crítico e autocrítica. Também reforçava acertadamente a necessidade de entender a criatividade como um processo necessário tanto nas artes quanto nas ciências e de valorizar o pensamento intuitivo (indutivo) em detrimento do pensamento analítico (dedutivo), geralmente estimulado na escola. Porém, as mudanças de 2006 refletem um peso menor da criatividade no domínio da inteligência, caracterizando esse último ainda mais como o domínio próprio dos alunos com AH/ SD com bom desempenho acadêmico, com ênfase nas áreas linguística e lógico-matemática. Gagné (1991) argumenta que Renzulli, ao mencionar que “... é normalmente a originalidade, a novidade ou a singularidade da contribuição da pessoa que chama para ela a atenção do público", refere-se "... aos indivíduos que podem ser considerados agentes de mudança, inovadores, inventores" (Gagné, 1991, p. 69). Gagné (1991, p. 70) não considera a criatividade necessária em atletas, músicos e professores que, segundo ele, são reconhecidos por seu desempenho interpretativo, e afirma que ela "... deve ser considerada como uma determinante importante do desempenho excepcional em certos campos, mas não em todos". Acrescenta, ainda, que a criatividade "... deve ser considerada como uma esfera de aptidões na qual a dotação pode ser expressa, mas não dentro de outras", e talvez, essa seja a razão pela qual Guenther retira os indicadores de criatividade do domínio da inteligência. Particularmente, considero que a criatividade está presente nos atletas, músicos e professores que criam conhecimento, e que são, conforme a definição de Renzulli (1986), superdotados do tipo produtivo-criativo; e, por ser um dos três grupamentos de traços que permitem identificar as AH/SD, seus indicadores deveriam ser incorporados a todas as áreas. 
Os outros talentos identificados na lista eram criatividade acentuada/talento artístico, talento psicossocial e talento psicomotor.

\section{Criatividade acentuada e/ou talento artístico/domí- nio da criatividade e pensamento criador}

Os indicadores destinados à identificação da criatividade (2000) deviam ser pelo menos quatro dentre os itens de superioridade na área artística (3); capacidade de crítica e autocrítica (8); persistência e comprometimento com a tarefa (10); originalidade e criatividade (13); perspicácia e capacidade de observação (17) e pensamento divergente (25), sendo os quatro últimos também comuns à capacidade e à inteligência geral; ou três desses itens, incluindo necessariamente os itens 3 e 13, que definem, respectivamente, a superioridade nas áreas de arte e educação artística e originalidade e criatividade (Guenther, 2000).

A questão 3 (melhores nas áreas de arte e educação artística) permitiria identificar o destaque em pelo menos cinco áreas que podem estar relacionadas ao talento artístico: linguística (poesia, literatura), musical (interpretação, composição), corporal-cinestésica (dança), interpessoal (teatro, cinema) e/ou espacial (pintura, desenho, escultura, fotografia, gravura etc.), mas não exclusivamente à criatividade. Embora normalmente a disciplina de Artes ou Educação Artística tenha seu foco nas artes plásticas (desenho e pintura, principalmente), existem escolas que também abrangem as demais artes, assim como projetos extracurriculares com algum desses focos. Dessa forma, a questão é muito ampla e, tendo que selecionar apenas dois alunos, corre-se o risco de que alunos com indicadores de AH/SD passem despercebidos.

Em 2006, Guenther avança na definição desse talento, denominando-o criatividade e pensamento criador, ampliando o conceito à produção de ideias, incorporando mais componentes da criatividade (intuição e pensamento intuitivo, fluência, sensibilidade e perceptividade) e acrescentando a característica própria das pessoas altamente criativas de serem 'quase sempre 'diferentes' e fora de 'padrões' do grupo" (Guenther, 2006, p. 37). Entretanto, dos indicadores de criatividade acentuada e/ou talento científico-matemático (Guenther, 2000), a autora retira a persistência e o compromisso com a tarefa
(10) e a atividade, perspicácia e observação (17), incorporando o tédio e o desinteresse (12), agregando a distração a esse item, e substituindo originalidade e criatividade (13) por originalidade e fluência na produção de ideias e ações. Isso acrescenta um indicador mais amplo de criatividade e pensamento criador (fluência na produção de ideias e ações), mas, ao mesmo tempo, ao retirar a persistência e o compromisso com a tarefa, a atividade, a perspicácia e a observação e ao acrescentar a distração o tédio e o desinteresse nas aulas como indicadores desse domínio, reforça o papel do bom desempenho escolar, que já era importante no instrumento, como indicação de AH/SD. Se bem não são percebidos no desempenho escolar de alunos com AH/ SD do tipo produtivo-criativo, porque, geralmente, não são os conteúdos escolares tradicionais pelos quais esse tipo de aluno demonstra seu destaque, é inegável que os indicadores retirados são próprios e necessários para a manifestação das AH/SD do tipo produtivo-criativo. Como poderia um cientista, um pintor ou um músico inovador manter a produção criativa e fluente de ideias e ações que demonstra seu destaque na sua área sem ter atividade, observação e perspicácia nem persistência e compromisso com a tarefa que lhes interessa, mesmo que, em sala de aula, fossem distraídos e se sentissem entediados?

\section{Talento psicossocial/domínio da capacidade socioafetiva e intrapessoal}

Pelo menos quatro dos indicadores correspondentes aos itens 4, 7, 14, 15, 16, 19 e 26 indicavam a criança com destaque nessa área que, conforme as questões da lista representavam, respectivamente, a superioridade em atividades extracurriculares, a participação e a presença em tudo dentro e fora da sala de aula, a sensibilidade aos outros e bondade; a preocupação com o bem-estar dos outros, a autoconfiança; a simpatia e popularidade e a capacidade de liderança. Guenther (2000) comentava ter constatado que a combinação dos itens 4, 7, 14 e 15 parecia indicar talento psicossocial na área de relações humanas, mas que somente a indicação nos itens 16 e 26 confirmava a liderança nesse talento. Como Gagné (1991), a autora afirma que “... essa área de talentos ainda não está muito clara, precisando melhores definições" (Guenther, 2000, p. 183). 
Na questão 4, o destaque em atividades extracurriculares, considerado para aferir a capacidade e inteligência geral e, também, o talento psicomotor, é um indicador extremamente abrangente, visto que essas atividades podem ser muito variadas. Por exemplo, um aluno pode participar de uma Olimpíada de Matemática ou de uma pesquisa em um laboratório, extracurricularmente, destacando-se nessa atividade, e esse indicador deveria ser utilizado para avaliar a capacidade de pensamento abstrato/talento científico-matemático, mas não necessariamente o talento psicossocial ou psicomotor. Da mesma forma, o destaque de um aluno em um grupo de teatro não poderia ser considerado um indicador de capacidade e inteligência geral propriamente (dentro da definição de Guenther), mas poderia, sim, ser considerado um indicador de criatividade e/ou talento artístico, e assim por diante. Assim, para ser um indicador mais preciso do talento psicossocial, a questão deveria investigar atividades extracurriculares que expressassem esse talento (por exemplo, liderança no grêmio escolar, organização de atividades culturais, representação de turma etc.).

Em sua obra de 2006, Guenther denomina esse talento de domínio da capacidade socioafetiva e intrapessoal, diferenciando duas vias de expressão: liderança (senso de grupo, sintonia com ele e irradiação de energia própria para ele) e relações humanas (profundo senso de justiça; respeito pelo outro; capacidade e gosto por cooperação; preocupação com os outros; qualidade de considerar e ouvir; bondade e amizade). Essas duas vias de expressão não parecem ser excludentes, mas, geralmente, complementares.

Dos indicadores apresentados na obra de 2000, a revisão de 2006 (p. 87) tira a segurança e a autoconfiança (16), incorporando as boas relações com colegas e professores à questão 19 e a persuasão à questão 26, certamente um atributo necessário para a liderança, e é importante acrescentá-lo como indicador do domínio da capacidade socioafetiva. Entretanto, a segurança e a autoconfiança são características muito marcantes em qualquer líder, que geralmente tem um desenvolvimento importante nas inteligências intra e interpessoal. A incorporação das boas relações com colegas e professores pode refletir esse desenvolvimento, mas, ao mesmo tempo, volta a lembrar a imagem do bom aluno. Não podemos esquecer que aqueles alunos comumente referidos como lideranças negativas, geralmente, revelam-se contra a autoridade personificada nos docentes, e não necessariamente têm boas relações com todos os colegas - geralmente, apenas com o grupo de liderados.

\section{Talento psicomotor/domínio das habilidades sensório-motoras}

Na lista, a indicação nessa área requeria a nomeação do aluno nos itens 4, 23 e 24, respectivamente, superioridade em atividades extracurriculares, em esportes e exercícios físicos e em habilidades manuais ou motoras. Talvez por ser uma área muito ampla, como afirma Gagné (1991, p. 69), “... os sistemas de classificação ainda são numerosos” e criar indicadores para apontar o destaque nessa área seja uma tarefa bastante árdua. Porém, entendo que os indicadores utilizados na lista são por demais amplos para limitar o número de crianças indicadas de uma forma muito drástica.

Existe uma variedade muito grande de atividades extracurriculares, esportes e exercícios físicos, habilidades manuais e motoras como para indicar apenas dois alunos. Se tomarmos como exemplo alunos com fantástico destaque na dança, no atletismo ou na escultura, provavelmente eles não seriam apontados pela lista, visto que os três indicadores em que a criança deve ser indicada para ser considerada um possível talento psicomotor geralmente são excludentes. $\mathrm{O}$ aluno com destaque na dança ou no atletismo não necessariamente terá destaque em habilidades manuais ou em esportes, assim como o que o tem na escultura (habilidade manual que envolve a inteligência espacial) não necessariamente o terá em esportes e exercícios físicos (habilidades motoras, vinculadas à inteligência corporal-cinestésica).

Em 2006, Guenther renomeia esse talento de domínio das habilidades sensório-motoras, saneando o conceito anterior que agora tem como indicadores as "habilidades sensório-motoras, o bom controle da mente sobre funções do sistema muscular e ósseo; talento esportivo; desempenho físico-motor qualitativamente superior; gosto e dedicação a atividades físicas" (Guenther, 2006, p. 37).

Dos três indicadores apresentados em 2000, a versão de 2006 retira o indicador de superioridade em atividades extracurriculares (4), acrescentando 
o "desempenho superior em dança e outras formas de expressão rítmica" e "extraordinário funcionamento dos sentidos: acuidade visual, sensibilidade auditiva, tátil, de olfato e gustativa" (p. 88) que não tinham questões próprias na lista de 2000. Embora esses indicadores reconheçam novas áreas de talento psicomotor, em relação à lista de 2000, eles continuam sendo excludentes entre si; e sem haver um esclarecimento quanto ao critério de avaliação na nova obra, esse domínio permanece bastante obscuro.

A nova configuração dos talentos em domínios (2006) contribui para aprimorar o nível de indicação dos alunos e corrige algumas das limitações que a lista de 2000 apresentava; entretanto, é importante ter em mente o conceito subjacente de inteligência e o caráter fundamentalmente cognitivo da dotação que ele tem.

Outros aspectos a serem considerados quando se utiliza essa lista, os quais podem prejudicar as indicações quando não se adotarem os cuidados necessários, são a heterogeneidade de conceitos que existem entre os professores, o papel exacerbadamente essencial que adquire o desempenho escolar e a subjetividade dos docentes, ao responder às questões.

\section{Três aspectos que podem prejudicar as indicações com a lista de itens para observação em sala de aula}

\section{A heterogeneidade de conceitos}

Guenther (2000, p. 177) afirma ser necessário que o docente compreenda "... os conceitos e termos empregados, evitando interferências de interpretações errôneas ou incompletas". Isso é fundamental para que a diversidade de significados que um termo pode adquirir não invalide a eficiência do instrumento na indicação de possíveis alunos com AH/SD.

Em seu contexto original, é menos provável que ocorram muitas divergências, visto que, no trabalho do CEDET, os professores são previamente preparados para o preenchimento da lista, visando uniformizar conceitos; mas, em outros contextos, devem ser cuidadosamente observados (e esclarecidos) aqueles conceitos capazes de gerar confusões ou erros de interpretação, alguns dos quais assinalo a seguir.
0 indicador de superioridade nas áreas de arte e educação artística (questão 3, lista de 2000), por exemplo, está vinculado a um determinado conceito de arte. Se o professor entender arte ou educação artística como o conteúdo normalmente oferecido no programa escolar, provavelmente não pensará naquele aluno que pode se destacar em algumas áreas artísticas (dança, poesia, literatura, teatro, escultura, pintura, música, fotografia, cinema); possivelmente, indicará aqueles alunos que desenham melhor, visto que, geralmente, esse é o ramo das artes mais explorado no ensino regular, especialmente, na rede pública.

A superioridade em atividades extracurriculares (questão 4, na lista de 2000, que, em 2006, é referida como interesse e sucesso ou gosto e participação em atividades extracurriculares), também coloca em pauta a abrangência dessas atividades. Comumente, atividades extracurriculares são todas aquelas desenvolvidas na escola, mas não previstas no programa escolar regular. Uma festa na escola ou uma atividade no contraturno, como os projetos que algumas escolas desenvolvem para seus alunos, são consideradas atividades extracurriculares. Porém, também poderiam ser incluídas aqui outras atividades que o aluno desenvolva fora da escola, como um curso de línguas, de música ou teatro; uma coleção de selos, moedas ou quaisquer outros objetos a que o aluno possa se dedicar, ou os estudos individuais que porventura possa fazer individualmente. Essas atividades extracurriculares raramente serão consideradas pelo professor em sua avaliação, principalmente porque são realizadas fora do contexto escolar.

0 indicador da questão 6 (lista de 2000) pedia ao professor que ele associasse três conceitos que não necessariamente andam juntos: curiosidade, interesse e manifestação verbal dessa curiosidade ou desse interesse. Guenther (2000, p. 177) afirma ser difícil distinguir "... uma criança curiosa, outra perguntadora e outra interessada, pois esses atributos aparecem combinados nas diversas situações, e não isoladamente nas pessoas". Entretanto, perguntar é apenas uma das formas de expressar a curiosidade - a verbal -, enquanto que uma criança pode expressar sua curiosidade e seu interesse mediante o tato, por exemplo, mexendo naquilo que lhe interessa, sem necessariamente perguntar sobre o que está investigando. Ser perguntador nem sempre é uma qualidade bem-vista por todos os professores; 
muitos se sentem intimidados ou incomodados com a criança que pergunta demais, avaliando essa característica como uma qualidade negativa. A definição de interessado pode limitar-se à atitude passiva de prestar atenção às palavras do professor e cumprir à risca todas as propostas de trabalho na sala de aula, não considerando a frequente atitude investigativa perante assuntos totalmente alheios à escola e aos conteúdos programáticos, também muito comum nos alunos com AH/SD. Daí depreende-se que curiosa, perguntadora e interessada são adjetivos não necessariamente concomitantes numa mesma criança e, principalmente, sujeitos a interpretações muito pessoais. Na versão de 2006, essa questão elimina a dubiedade com a nova redação Curiosidade e interesses amplos e variados, corrigindo a dificuldade de interpretar e associar aqueles conceitos.

A questão 13 (lista de 2000) propunha o desafio de conceituar originalidade e criatividade. A originalidade é um dos componentes da criatividade consensuais em grande parte das definições (Lubart, 2007; Boden, 1999; Wechsler, 1998), mas, como a criatividade, geralmente é diretamente vinculada à atividade artística e não é raro estabelecer uma sinonímia entre criatividade e arte, sem percebê-la na atividade científica, por exemplo, ou em outras áreas do saber e do fazer humano. Guenther (2000, p. 71) também defende essa ideia com muita clareza, e comenta que "... a educação não tem conseguido, via de regra, integrar e operacionalizar" na prática, a relação desejável entre criatividade e produção científica. Embora, na revisão de 2006, o indicador fique mais bem formulado ao substituir-se o termo criatividade por fluência na produção de ideias e ações, ele passa a ser exclusivo do domínio da criatividade e pensamento criador, sendo retirado do domínio da inteligência e capacidade intelectual, para o qual seriam indicados os alunos que apresentam destaque nas ciências. Assim, aqueles que apresentam características de um potencial produtor de conhecimento na área das ciências, que envolve a criatividade, podem passar despercebidos.

Na questão 17 (lista de 2000) também se fundiam três conceitos diferentes que não sempre são concomitantes: atividade, perspicácia e observação. Uma criança pode ser observadora e, em consequência, ser perspicaz (perceber sutilezas e complexidades com clareza), mas pode ser uma criança que não se manifesta na aula, que guarda tudo para si e, assim, não ser identificada como ativa e, ao não apresentar a concomitância, ser descartada na indicação. Na versão de 2006, acrescentam-se dois novos adjetivos que incorporam novas dificuldades: vivacidade e sintonia - conceitos aparentemente simples, porém também sujeitos a múltiplas interpretações, principalmente quando associados aos outros três.

A questão 18 (2000) propunha conceituar $c a-$ pacidade de pensamento e capacidade de tirar conclusões. Felizmente, a revisão de 2006 acrescenta o adjetivo analítico para qualificar o pensamento, esclarecendo a questão ao solicitar a indicação dos alunos que apresentam Pensamento analítico, capazes de pensar e tirar conclusões, característica bastante comum nas PAH/SD.

A questão 20 parece não fazer mais parte da lista, na revisão de 2006, o que evita ter que indicar uma criança solitária e, ao mesmo tempo, ignorada. Uma criança pode ser solitária e, justamente por isso, não ser ignorada pelos demais alunos, pois chama a atenção por seu comportamento diferenciado. Por outro lado, uma criança pode estar constantemente querendo fazer parte de grupos e ser ignorada pela turma, o que não é raro acontecer com a criança que é ou se sente rejeitada pelo grupo.

Felizmente, a questão 22 não aparece mais relacionada nos indicadores da revisão de 2006, pois a resposta a essa pergunta envolvia um conceito de inteligência subjacente que poderia estar baseado em diferentes teorias (única, fatorial, multifatorial, multidimensional). Um professor que tivesse como referencial implícito o conceito de inteligência única, fatorial, ou mesmo multifatorial, tenderia a indicar aqueles alunos com melhor raciocínio lógico-matemático, melhor vocabulário, maior fluência verbal, melhor capacidade de memorização e pensamento abstrato mais desenvolvido, dentre outros. Entretanto, um professor que tivesse como referencial a TIM, teria muita dificuldade em identificar apenas dois alunos, sem sentir-se obrigado a hierarquizar as inteligências.

Na questão 24, inalterada na versão de 2006, há concomitância de dois tipos de habilidades não equivalentes: manuais e motoras. A criança com maior habilidade manual apresenta um desenvolvimento superior da motricidade fina, geralmente vinculado a atividades artísticas ou artesanais, enquanto a superioridade na motricidade ampla normalmente se expressa nos esportes, no atletismo, na dança, nas artes marciais. Unir os dois tipos de 
habilidade numa única questão pode levar o professor a procurar uma criança que apresente alto desempenho em ambas as áreas, ou mesmo que tenha que privilegiar uma das duas.

Finalmente, o indicador acrescentado em 2006 no domínio das habilidades sensório-motoras Extraordinário funcionamento dos sentidos: acuidade visual, sensibilidade auditiva, tátil, de olfato e gustativa - parece ter a intenção de ampliar as áreas desse domínio que, na versão de 2000, eram apenas três (atividades extracurriculares, superioridade nos esportes e exercícios físicos e superioridade em habilidades manuais e motoras). Esse indicador pode permitir indicar alunos que apresentam superioridade na música, por exemplo, mas permanece muito obscuro e demasiado amplo. Será que em um aluno que simplesmente tenha um dos sentidos extremamente aguçados - como, num caso extremo, as pessoas cegas ou surdas, que geralmente aprimoram o funcionamento de algum desses sentidos muito mais do que as demais pessoas - isso seria suficiente para indicar um "talento sensório-motor" ou AH/SD na área corporal-cinestésica ou musical? Da mesma forma, somente o desempenho superior na dança pode ser o resultado de um treinamento apurado, mas, sabe-se que, por si só, não permite afirmar que essa criança tenha $\mathrm{AH} / \mathrm{SD}$ na dança, o que também nos faz refletir sobre o papel fundamental do desempenho escolar na lista.

\section{0 papel do desempenho escolar}

Apesar de correlacionar estreitamente talento e desempenho, tanto Gagné (1991) quanto Guenther (2000) questionam corretamente o excessivo uso do desempenho escolar para identificar crianças com AH/SD. "É importante diferenciar o potencial indicado pelos instrumentos psicométricos do desempenho observado numa determinada área" (Gagné, 1991, p. 71); detectar os sinais diferenciados de talento e não nos apoiar demasiadamente na produção ou no desempenho; "porque existe indicação de que considerável número de 'crianças-prodígio' tornam-se 'adultos normais'” (Guenther, 2000 , p. 87), e até porque muitos dos talentos reconhecidos pela humanidade "nem mesmo demonstraram estar acima da média do grupo de pares na infância, mormente sob a ótica da escola" (Guenther, 2000, p. 87).
Gagné (1991, 2009), Guenther (2000), Feldhusen (1995), Renzulli $(1979,1986)$, bem como muitos outros autores, declaram ser importante considerar que o desempenho superior ou o desenvolvimento das aptidões depende da estimulação, do apoio e das oportunidades geradas pelo ambiente onde a pessoa vive, visto que se não existirem essas condições na escola, a confiabilidade da indicação diminui.

O desempenho escolar é um referencial muito forte na lista, visto que a indicação do aluno acontece a partir da avaliação do corpo docente da escola que observará essa criança na sala de aula e somente poderá ter como referência o desempenho dessa criança no âmbito escolar. Na experiência do CEDET, o facilitador também é uma das fontes de observação, o que não acontece quando a lista é utilizada fora desse contexto; porém, é preciso que o aluno seja indicado por duas fontes, o que desfavorece o facilitador frente a duas fontes de indicação puramente escolares.

Também, é importante observar que, no modelo do CEDET, o atendimento decorrente da indicação da criança depende do desempenho escolar, pois ela é afastada do programa em caso de repetência. Embora Guenther (2000) argumente que essa medida é adotada para que o aluno não negligencie ou despreze a ação dos educadores (na escola) e que o bom desempenho não é, por si só, suficiente para ingressar ao CEDET, a mensagem que o aluno com $\mathrm{AH} / \mathrm{SD}$ atendido no CEDET recebe é que o bom desempenho escolar é o que comprova os indicadores de AH/SD.

Assim, é preciso ter extremo cuidado para não correr o risco de que sejam indicados somente os alunos que apresentam indicadores observáveis na escola exclusivamente e, no atendimento decorrente, analisar a falta de desempenho escolar sob outra ótica, sem esquecer que, não raramente, a criança com AH/SD pode ser uma criança com subdesempenho (underachiever) ou mesmo com dificuldades de aprendizagem em alguma área (Holocher-Ertl, Kubinger, Hohensinn, 2008).

Esse cuidado está fundamentado, pelo menos, em duas razões que Guenther (2000), inclusive, comenta. A primeira é que, embora o desempenho escolar não possa ser eliminado como elemento indicador de AH/SD, “... pois essa também é uma área de produção, onde a criança pode expressar suas capacidades" (Guenther, 2000), é imprescindível 
considerarmos outros campos de aferição das AH/ SD, já que "as situações de simples desempenho escolar, da mesma forma que a produção de respostas em testes, são demasiadamente focalizadas em uma estreita gama de habilidades identificáveis, dispondo de poucas vias para expressão de talento" (Guenther, 2000, p. 96). A outra razão é que, embora existam evidências claras de que as condições socioeconômicas não afetam a distribuição das $\mathrm{AH} /$ SD, ou seja, os alunos com AH/SD estão distribuídos nas diferentes classes sociais na mesma proporção que as demais pessoas (Chagas, 2003; Guenther, 2000, 2006; Pérez, 2004, 2008), o desempenho escolar sofre os efeitos das carências socioeconômicas. Dentre os aspectos socioeconômicos capazes de influenciar negativamente o desempenho escolar encontramos alguns que, se bem não são exclusivamente encontrados nas classes mais desfavorecidas, têm incidência maior nelas, por exemplo: trabalho infantil, residência familiar incerta (que ocasiona a constante mudança de escolas), famílias desestruturadas, falta de desenvolvimento de hábitos de estudo, falta de acesso a recursos culturais (livros, teatro, cinema, museus), analfabetismo dos pais e não valorização da escola. Outra razão a ser acrescentada é que o "desempenho destacado" requer especialização em alguma área, o que exige tempo e, frequentemente, o destaque constata-se na adolescência ou na vida adulta, aparecendo apenas como um potencial, na infância.

\section{A subjetividade do professor}

A subjetividade do professor também é um elemento que interfere na interpretação da lista. Muitos professores tendem a nomear os alunos com os quais têm mais afinidade, pelos quais sentem mais simpatia ou mesmo aqueles que têm as melhores notas, deixando de lado o aluno que incomoda, que conversa em aula, que parece não prestar atenção, mesmo possuindo algum dos indicadores. Na minha experiência, quando os professores são previamente informados sobre o objetivo da lista, aqueles que "não acreditam" na existência de alunos com AH/SD ou que estão influenciados pelos mitos sociais e culturais sobre as AH/SD, muitas vezes, esforçam-se para nomear a grande maioria dos alunos, distribuindo seus nomes aleatoriamente nas questões. Muitas vezes, o professor faz isso para provar que todos os alunos são inteligentes ou que todos os alunos são iguais, quando não para preservar seu sentimento de competência, por acreditar que o bom rendimento dos alunos reflete a qualidade profissional do seu trabalho. Guenther (2000, p. 226) acrescenta que, numa pesquisa desenvolvida com alunos atendidos no CEDET, “... sempre que houve algum problema identificável entre o CEDET e a escola, aumentou ali o número de indicações erradas", reforçando o papel da subjetividade na indicação.

As três primeiras questões da lista foram desenhadas para permitir que os professores indiquem os alunos com melhor desempenho escolar logo de início (Guenther, 2000), tentando minimizar essa subjetividade, mas, o forte arraigo dos indicadores no desempenho, mesmo nas áreas não tão valorizadas pela escola, prejudica essa intenção. Todos os indicadores determinados para aferir o domínio da capacidade socioafetiva e o domínio das habilidades sensório-motoras implicam uma mensuração do bom desempenho e, portanto, do bom aluno. Os elementos considerados para a indicação na área socioafetiva, por exemplo, têm uma conotação positiva, embora já se tenha constatado que muitos líderes negativos na nossa sociedade foram e são PAH/ SD (poderíamos negar-lhe a Hitler essa condição?).

Mesmo no domínio da criatividade e pensamento criador, os indicadores de superioridade em arte ou educação artística e de distração, tédio e desinteresse nas aulas têm como referência o bom desempenho escolar e, portanto, estão muito vinculados à subjetividade do professor. Talvez três das questões que permitem elencar indicadores de criatividade [capacidade de crítica e autocrítica, originalidade e fluência na produção de ideias e ações, e pensamento divergente] não estejam diretamente relacionadas ao bom desempenho escolar sob uma perspectiva mais tradicional, centrada na transmissão de informações, mas, acabam sendo-o por representarem características geralmente não desejadas no bom aluno pelos professores, como já foi apontado por alguns autores (Alencar, 2001, 2007; Landau, 1986; Torrance, 1976).

Por isso, é importante utilizar outros instrumentos que colham informações de outras fontes (por exemplo, familiares, colegas, e a própria criança) para completar o processo de identificação, como uma forma de minimizar a subjetividade dos professores que, como Guenther (2000, p. 180) afirma, 
"... privilegiam os alunos com melhor desempenho escolar" e podem distorcer as observações. Pesquisas (Benito Mate, 1996; Renzulli, 1986, 2003; Pérez, 2004, 2008) têm comprovado que a família e os colegas são outras fontes de dados confiáveis e importantes. Na minha experiência, tenho utilizado com sucesso a lista de itens como instrumento de triagem inicial, mas sempre associada a outros instrumentos aplicados a outras fontes, à observação e à entrevista (Pérez, 2004, 2008), que permitem elencar diferentes indicadores que a lista não utiliza ou refere a outro referencial teórico de inteligência e investigá-los fora do contexto escolar.

\section{Por que a lista de itens para observação em sala de aula deve ser usada com muito cuidado quando o conceito referencial de inteligência e de Altas Habilidades/Superdotação é multidimensional?}

Após essa análise, conclui-se que o instrumento limita a indicação de alunos com AH/SD quando se utiliza como referência teórica a Teoria das Inteligências Múltiplas (TIM) (Gardner, 1983, 2000) e a Teoria de Superdotação dos Três Anéis de Renzulli $(1979,1986)$, o que acontece em grande parte do Brasil.

No Quadro 4, estão apresentados todos os indicadores vinculados a cada domínio, segundo os critérios de Guenther (*), e as inteligências adicionais que cada indicador poderia apontar (柴), quando observado à luz da TIM.

Como se pode observar, a partir das considerações anteriores e do Quadro 4, nove dos $27^{1}$ indicadores, segundo os critérios de Guenther (2006), de fato, assinalam destaque em alguma das inteligências múltiplas; porém, como a concepção de inteligência da lista é a do fator " $G$ ", apenas as inteligências linguística e lógico-matemática são associadas ao domínio da inteligência e capacidade intelectual. As demais inteligências, segundo a TIM, são entendidas como habilidades ou talentos específicos (inteligência espacial, associada à criatividade e pensamento criador; inteligência interpessoal, associada ao domínio da capacidade socioafetiva; e inteligências corporal-cinestésica, espacial e musical, associadas ao domínio de habilidades sensório-motoras). Se analisarmos os indicadores mais detalhadamente, de acordo com o referencial multidimensional, poderíamos apontar 21 deles que permitem assinalar o destaque em mais de uma inteligência, e sete deles em quaisquer das oito inteligências.

No que se refere ao conceito de AH/SD, de acordo com a Teoria de Superdotação dos Três Anéis (Renzulli, 1979, 1986), tanto o comprometimento com a tarefa quanto a criatividade são grupos de traços definitórios do comportamento de AH/SD e devem estar presentes - ou, pelo menos, potencialmente presentes - em todas as áreas de AH/SD. Segundo os critérios de Guenther (2006), o compromisso com a tarefa e a persistência são associados, exclusivamente, ao domínio da inteligência e da capacidade intelectual, e, dos indicadores mais diretamente vinculados à criatividade (agrupados no Quadro 4), apenas quatro são associados ao domínio da criatividade e pensamento criador, enquanto os demais (6) são associados apenas ao domínio da inteligência e da capacidade intelectual.

A persistência e compromisso nas tarefas abraçadas e a independência, autonomia, iniciativa, por exemplo, são características gerais que devem ser contextualizadas, ou seja, devem ser consideradas sempre em relação às atividades de interesse da criança (e não às tarefas propostas pelo professor, apenas). São elementos-chave do comprometimento com a tarefa, no qual estão incluídas a motivação e a persistência, como diferencial para identificar as AH/SD. Outros autores também apontam esses dois componentes nas AH/SD (Feldhusen, 1995; Mönks, 1992; Sternberg, 2003). No seu modelo diferenciado de superdotação e talento, Gagné (1991, p. 71) coloca a motivação como um dos catalisadores, ou seja, "moderadores positivos (ou negativos) que transformam (ou não) as aptidões em talentos" intrapessoais (que também incluem a curiosidade, a perseverança, a autonomia etc.). 0 mesmo autor questiona o uso da motivação como uma característica da superdotação na definição de Renzulli (1979) (referindo que este último a denomina de "comprometimento com a tarefa") porque isso dificulta a explicação do subdesempenho

1 Dois indicadores (participação em atividades extracurriculares e presença constante dentro e fora da sala de aula) são atribuídos ao domínio da inteligência e ao domínio da capacidade socioafetiva.

Psicol. Argum. 2013 jan./mar., 31 (72), 57-78 
Pérez, S. G. P. B.

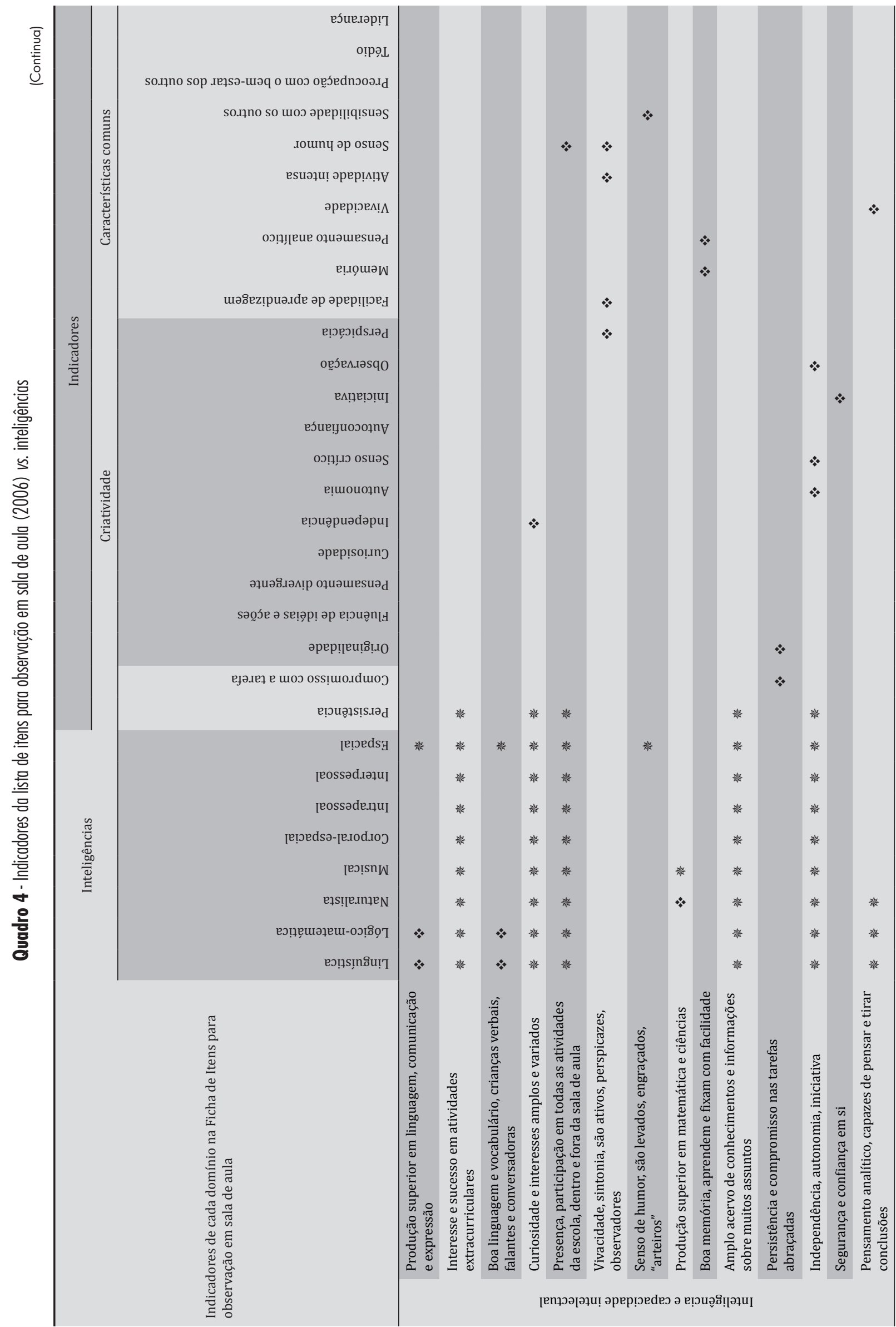




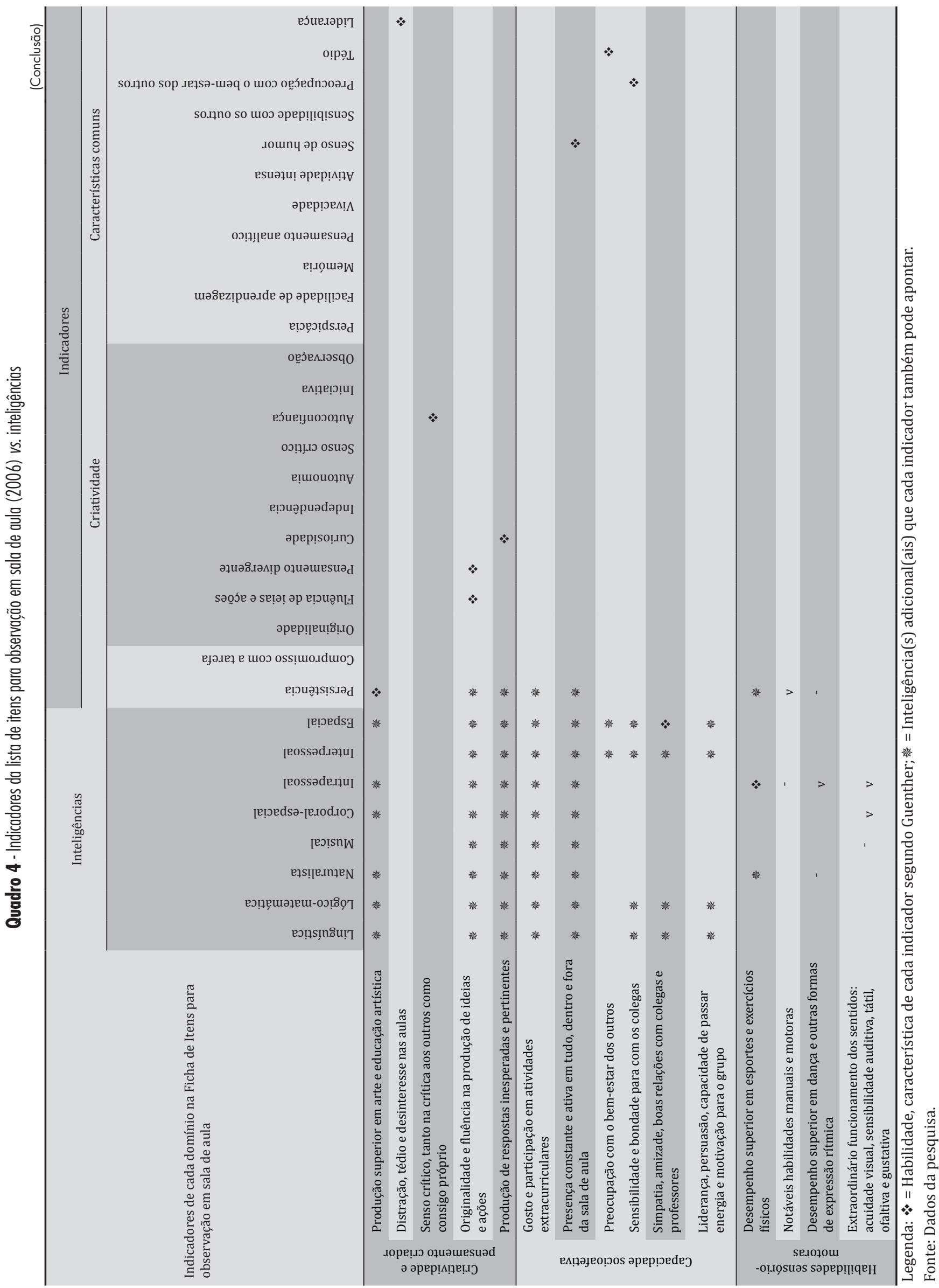


(underachievement), mesmo na presença de uma capacidade intelectual altamente superior. $\mathrm{O}$ autor afirma que uma criança com escore de $130 \mathrm{ou}$ mais num teste de QI não poderia deixar de ser considerada dotada porque não tenha um desempenho acadêmico equivalente.

Quanto a essa afirmação, duas questões devem ser consideradas. A primeira é que motivação e comprometimento com a tarefa não são sinônimos. No modelo de Renzulli, a motivação é um dos componentes do comprometimento com a tarefa, estando este anel sujeito às influências de características de personalidade e ambientais que, segundo autores que têm pesquisado o subdesempenho (Baum, Renzulli \& Hébert, 1995; Mahoney, 1999), são fatores que explicam esse fenômeno. A segunda é que, na afirmação de Gagné (1991), há uma sinonímia questionável entre motivação e sucesso (acadêmico), visto que o comprometimento com a tarefa deve ser considerado em relação à área de AH/SD da criança e não ao desempenho escolar. Uma criança com AH/SD na área da música, por exemplo, não necessariamente demonstrará comprometimento com as aulas de matemática ou de ciências, mas o expressará no seu amor pela música.

Na literatura especializada, encontramos algumas características recorrentemente mencionadas por diferentes autores como gerais nas PAH/SD, dentre elas: persistência; vocabulário rico e fluência verbal; sensibilidade e empatia em relação aos outros; intensa motivação; preocupações éticas e estéticas precoces; senso de humor; facilidade e rapidez de aprendizagem; persuasão e capacidade de influenciar os demais; memória; interesses variados; pensamento abstrato desenvolvido; compromisso com a tarefa; rendimento acadêmico destacado ou (rendimento abaixo da média); gosto pela leitura e nível elevado de leitura; incluindo-se também nessa lista, indicadores geralmente vinculados à criatividade (originalidade; fluência de ideias; pensamento divergente; curiosidade; independência; autonomia; senso crítico desenvolvido; autoconfiança; iniciativa; liderança; poder de observação muito desenvolvido; gosto pelos desafios; desgosto com a rotina) (Acereda Extremiana, 2000; Alencar \& Fleith, 2001, 2007; Novaes, 1979; Pérez, 2004, 2008; Prieto Sánchez \& Castejón Costa, 2000; Renzulli \& Reis, 1997; Virgolim, 2007).

A maioria dessas características corresponde a dez indicadores comumente associados à criatividade e aos 11 indicadores $(14$ características) restantes (no Quadro 3, agrupados sob o título Características comuns). Quatro características, que Guenther (2006) define como indicadores do domínio da criatividade e pensamento criador (exceto o destaque em artes e educação artística), na percepção de Renzulli (1979, 1986, 1997, 2004), são mais frequentes no aluno com características mais acentuadas do tipo produtivo-criativo, mas não são próprios de uma área de superdotação específica.

Quatorze dessas características são atribuídas ao domínio da inteligência e capacidade intelectual. Dos seis indicadores do domínio da capacidade socioafetiva, três contemplam características gerais frequentemente mencionadas na literatura e somente o que denota "Simpatia, amizade, boas relações com colegas e professores" poderia ser mais associado às $\mathrm{PAH} / \mathrm{SD}$ na área interpessoal, mais especificamente.

Os indicadores do Domínio das habilidades sensório-motoras, sim, são exclusivos da área corporal-cinestésica, embora, como já foi mencionado, muito amplos para identificar uma área específica de destaque.

\section{Considerações finais}

Embora a lista de itens para observação em sala de aula não possa ser utilizada eficientemente com referenciais teóricos de inteligência e de Altas Habilidades/Superdotação diferentes dos que embasam o instrumento, todos os seus indicadores podem ser válidos.

Quando enfocados na área de maior destaque da criança, e não apenas no desempenho escolar, e quando considerada uma teoria de inteligência e uma teoria de superdotação multidimensionais, esses indicadores (ou características) adquirem dimensão bem diferente e podem ser, sob outra configuração e com outros critérios, grandes aliados para a identificação.

Deve ficar muito claro para os educadores que utilizem a lista de Guenther que: 1) ela não é um instrumento de identificação final, mas um instrumento de indicação; 2) o tipo de aluno indicado com esse instrumento, geralmente, será apenas aquele que apresenta um desempenho comprovado na escola, particularmente o do tipo acadêmico em áreas cognitivas; 3) a aplicação do instrumento deve ser 
precedida de preparação prévia dos professores para eliminar ao máximo os possíveis desvios resultantes da heterogeneidade de conceitos e da subjetividade; e 4) a lista pode ser utilizada com outros instrumentos que complementem as informações e, especialmente, que investiguem os indicadores de $\mathrm{AH} / \mathrm{SD}$ em áreas não cognitivas.

Numa realidade como a nossa, na qual a identificação é ainda quase inexistente como prática nas escolas; na qual os professores estão e/ou sentem-se assoberbados de tarefas mais administrativas do que educacionais que restringem ainda mais o seu tempo ou na qual a formação inicial e continuada dos docentes (inclusive dos professores especialistas em Atendimento Educacional Especializado) raras vezes inclui o tema das Altas Habilidades/ Superdotação, a utilização de um instrumento de triagem pode contribuir para tirar da invisibilidade pelo menos alguns alunos com AH/SD. 0 re(conhecimento) dessa parcela de alunos com necessidades educacionais especiais é fundamental para impulsionar o adequado registro no Censo Escolar e a consequente distribuição de recursos do FUNDEB para as escolas de origem e, o que é mais importante, a formulação de políticas públicas educacionais que permitam um efetivo atendimento educacional especializado para esses alunos.

\section{Referências}

Acereda Extremiana, A. (2000). Niños superdotados. Madrid: Pirâmide.

Alencar, E. M. L. S., \& Fleith, D. S. (2001). Criatividade $e$ educação de superdotados. Petrópolis, RJ: Vozes.

Alencar, E. M. L. S. (2007). Indivíduos com altas habilidades/superdotação: Clarificando conceitos, desfazendo ideias errôneas. In D. S. Fleith (Org.). A construção de práticas educacionais para alunos com altas habilidades/superdotação. Brasília, DF: MEC/SEESP.

Associação Brasileira para Superdotados - Seção Rio Grande do Sul, [ABSD-RS]. (2001). Relatório final da pesquisa sobre Portadores de Altas Habilidades Região Metropolitana de Porto Alegre. Porto Alegre, RS: ABSD-RS.
Baum, S. M., Renzulli, J. S., \& Hébert, T. (1995). The Prism Metaphor: A new paradigm for reversing underachievement. Storrs, CT: University of Connecticut.

Benito M, Y. (1996). Inteligencia y algunos factores de personalidad en superdotados. Salamanca, Espanha: Amarú.

Boden, M. A. (Org.). (1999). Dimensões da criatividade. Porto Alegre, RS: Artmed.

Brasil. (1997) Parâmetros curriculares nacionais: Ciências naturais. Brasília, DF: MEC/SEF.

Brasil. (2008a). Política Nacional de Educação Especial na Perspectiva da Educação Inclusiva. Brasília, DF: MEC/ SEESP.

Brasil. (2008b). Decreto n. 6571, de 17 de setembro de 2008. Dispõe sobre o atendimento educacional especializado, regulamenta o parágrafo único do art. 60 da Lei n. 9.394, de 20 de dezembro de 1996, e acrescenta dispositivo ao Decreto n. 6.253. Diário Oficial da União, Brasília, 17 set. 2008. Recuperado em 13 nov. 2007, de http://www.planalto.gov.br/ccivil_03/_ato2007-2010/2008/Decreto/D6571.htm.

Brasil. (2009). Resolução no 4, de 2 de outubro de 2009. Institui Diretrizes Operacionais para o Atendimento Educacional Especializado na Educação Básica, modalidade Educação Especial. Brasília: Diário Oficial da União, Brasília, 5 out. 2009, Seção 1, p. 17.

Chagas, J. F. (2003). Características familiares relacionadas ao desenvolvimento de comportamentos de superdotação em alunos de nível socioeconômico desfavorecido. Dissertação de Mestrado, Faculdade de Psicologia da Universidade de Brasília, DF.

Feldhusen, J. F. (1991). Saturday and Summer Programs. In N. Colangelo \& G. A. Davis (Ed.). Handbook of Gifted Education. Needhan Heights, MA: Allyn and Bacon.

Feldhusen, J. F. (1995). Identificación y desarrollo del talento en la educación (TIDE). Ideacción, 4.

Feldhusen, J. F. (2003). Emparejamientos óptimos: Alumnos, padres, profesores, curricula, compañeros, entorno. In J. A. Alonso, J. S. Renzulli \& Y. Benito Mate. Manual internacional de superdotados. Manual para profesores y padres. Madrid: EOS. PMid:14605791. 
Gagné, F. (1991). Toward a differentiated model of giftedness and talent. In N. Colangelo \& G. A. Davis (Ed.). Handbook of Gifted Education. Needhan Heights, MA: Allyn and Bacon.

Gagné, F. (2009). Building gifts into talents: Brief overview of the DMGT 2.0. National Conference on Gifted Education. Reaching forward... Achieving sustainability in Gifted Education!. March 13-15, 2009. Rotorua, New Zeland. Retrieved 29 jul. 2009, from www.giftedconference2009.org/.../gagne_p12_therealnature.pdf.

Gardner, H. (1983). Frames of mind: The theory of multiple intelligences. New York: Basic Books.

Gardner, H. (2000). Inteligência: Um conceito reformulado. Rio de Janeiro, RJ: Objetiva.

Guenther, Z. C. (2000). Desenvolver capacidades e talentos: Um conceito de inclusão. Petrópolis, RJ: Vozes.

Guenther, Z. C. (2006). Capacidade e Talento. Um programa para a escola. São Paulo, SP: EPU.

Holocher-Ertl, S., Kubinger, \& K. D., Hohensinn, C. (2008). Identifying children who may be cognitively gifted: The gap between practical demands and scientific supply. Psychology Science Quarterly, 40(2), 97-111.

Landau, E. (1986). Criatividade e superdotação. Rio de Janeiro, RJ: Eça Editora.

Lubart, T. (2007). Psicologia da criatividade. Porto Alegre, RS: Artmed.

Mahoney, A. S. (1999). Giftedness and academic underachievement: What lies beneath. Advanced Development Journal, 8.

Mönks, F. J. (1992). Development of gifted children: The issue of identification and programming. In W. A. M Peters. Talent for the future. Assen: Van Gorcum. PMCid:364593.

Novaes, M. H. (1979). Desenvolvimento psicológico do superdotado. São Paulo: Atlas.

Pérez, S. G. P. B. (2004). Gasparzinho vai à escola: Um estudo das características do aluno com altas habilidades produtivo-criativo. Dissertação de Mestrado, Faculdade de Educação da Pontifícia Universidade Católica do Rio Grande do Sul, Porto Alegre, RS.
Pérez, S. G. P. B. (2008). Ser ou não ser, eis a questão: O processo de construção da identidade na Pessoa com Altas Habilidades/Superdotação adulta. Tese de Doutorado, Faculdade de Educação da Pontifícia Universidade Católica do Rio Grande do Sul, Porto Alegre, RS.

Prieto Sánchez, M. D., \& Castejón Costa, J. L. (2000). Los superdotados: Esos alumnos excepcionales. Málaga, ES: Aljibe.

Renzulli,J.S.(1979).What Makes Giftedness? Reexamining a Definition. Chronicle Guidance Professional Service P991. (pp. 1-6). Moravia: Chronicle Guidance.

Renzulli, J. S. (1986). The Three-ring conception of Giftedness: A developmental model for creative productivity. In J. S. Renzulli \& S. M. Reis. (Ed.). The Triad Reader. Mansfield CT: Creative Learning Press.

Renzulli, J. S. Parent and peer ratings in the identification process. Connecticut: NEAG - Center for Gifted Education and Talent Development. Recuperado em 1 jul. 2003, de http://www.sp.uconn.edu/ nrcgt/sem.

Renzulli, J. S. (2004). O que é essa coisa chamada Superdotação, e como a desenvolvemos? Uma retrospectiva de vinte e cinco anos. Educação, 1(52), 45-130.

Renzulli, J. S., \& Reis, S. M. (1997). The Schoolwide Enrichment Model: A how-to guide for educational excellence. Mansfield, CT: Creative Learning Press.

Sternberg, R. J. (2003). WICS as a model of giftedness, high ability studies, 14(2), 109-137. doi:10.1080/13 59813032000163807.

Torrance, E. P. (1974). Encouraging creativity in the classroom. 5th. ed. Dubuque: Brown.

Torrance, E. P. (1976). Criatividade: Medidas, testes e avaliações. São Paulo, SP: IBRASA.

Virgolim, A. M. (2007). Altas Habilidades/Superdotação: Encorajando potenciais. Brasília, DF: MEC/SEESP.

Wechsler, S. M. (1998). Criatividade. Descobrindo e encorajando. Campinas, SP: Psy. 